\title{
ASPEK MINAT PADA SISWI KELAS XI SMAN 4 PALU TERHADAP PEMBELAJARAN PENDIDIKAN JASMANI
}

\author{
Suaib Nur ${ }^{1}$, Muhammad Ismail ${ }^{2}$, Mohamad Rizal Suharto ${ }^{3}$ Muhammad Razak Abduh $^{4}$ \\ ${ }^{1}$ Universitas Muhammadiyah Palopo \\ Email: suaibnur050@gmail.com \\ ${ }^{2}$ Universitas Tadulako \\ Email: mail.jaket@gmail.com \\ ${ }^{3}$ Universitas Tadulako \\ Email: mrizalsuharto13@gmail.com \\ ${ }^{4}$ Universitas Muhammadiyah Palopo \\ Email: Nafeezaabduh@gmail.com
}

\begin{tabular}{l}
\hline \multicolumn{1}{c}{ Journal info } \\
\hline Jurnal Pendidikan Glasser \\
p-ISSN : 2579-5082 \\
e-ISSN : 2598-2818 \\
DOI : $10.32529 /$ glasser.v5i2.727 \\
Volume : 5 \\
Nomor : 2 \\
Month : 2021 \\
Issue : Oktober
\end{tabular}

\begin{abstract}
Abstrak.
Guru pendidikan jasmani yang berwenang sepatutnya mendesain strategi pembelajaran yang efektif untuk mengatasi permasalahn yang dihadapi oleh siswa. Tujuan penelitian ini adalah untuk mendeskripsikan seberapa besar minat siswi terhadap Pembelajaran Pendidikan Jasmani. Jenis penelitian ini adalah penelitian kualitatif. Lokasi penelitian ini adalah SMA Negeri 4 Palu. Data dalam penelitian ini dikumpulkan dengan memakai teknik angket. Jenis angket yang dipakai adalah angket tertutup. Untuk hasil data di peroleh sebesar 76,67\% intrinsik dalam diri dan $74,40 \%$ diperoleh faktor dari luar ekstrinsik. Kesimpulan dalam penelitian ini, bahwa minat siswi pada Pembelajaran Pendidikan Jasmani SMA Negeri 4 Palu di pengaruhi oleh dua faktor yaitu faktor dari dalam diri (intrinsik) dan faktor dari luar (ekstrinsik).
\end{abstract}

Keywords : Siswi, Minat, Pendidikan Jasmani

\section{A. PENDAHULUAN}

Pendidikan adalah sesuatu yang sangat krusial untuk manusia. Pendidikan bisa memberikan efek perkembangan manusia dalam seluruh aspek kepribadian dan kehidupannya ke arah yang positif. Pendidikan merupakan sarana utama pembentukan generasi penerus bangsa. Semakin baik mutu pendidikan, maka akan semakin baik pula bangsa tersebut.

Pendidikan jasmani adalah salah satu bentuk konstribusi dari program pendidikan secara umum, terutama melalui pengalaman gerak untuk menjamin pertumbuhan dan perkembangan anak. Pendidikan jasmani adalah sesuatu yang tak terpisahkan dari pendidikan dengan beresensikan pengalaman gerak yang memacuh kemampuan tubuh, keterampilan gerak, kemajuan kognitif, perkembangan sosialemosional dan kerohanian. Menurut BNSP (dalam Sudirjo dan Alif, 2019: 5), Pendidikan Jasmani adalah suatu proses pembelajaran $n$ menggunakan aktivitas jasmani yang didesain untuk meningkatkan kebugaran jasmani, mengembangkan keterampilan motorik, pengetahuan dan perilaku hidup sehat dan aktif, sportif, dan kecerdasan emosi. 
Oleh sebab itu, dalam Pendidikan Jasmani, proses belajar mengajarnya harus perlu senantiasa mendapatkan penataan. Dalam hal ini, meskipun yang berkewajiban mengembangkan kegiatan belajar mengajar dan hasil belajar yang maksimal merupakan tugas pengajar, tetapi salah satu faktor yang dapat mempengaruhi tinggi rendahnya mutu pendidikan adalah aspek psikokologis siswa itu sendiri. Beberapa di antaranaya adalah kecerdasan, tingkah laku, bakat, motivasi dan minat belajar siswa itu sendiri.

Minat belajar adalah suatu rasa lebih suka dan rasa ketertarikan pada aktivitas belajar tanpa ada yang menyuruh. Minat belajar akan ditandai dengan: rasa suka terhadap belajar daripada kegiatan lain, rasa keterkaitan dengan kegiatan belajar, menyukai kegiatan akademis, dan memiliki partisipasi yang tinggi terhadap belajar (Slameto dalam Syahputra, 2020:14). Dengan kata lain, apabila seseorang mempelajari dengan memiliki minat diharapkan bisa berhasil dengan baik dalam mempelajari hal tersebut.

Ringkasnya, seseorang yang memiliki minat yang tinggi untuk mempelajari suatu mata pelajaran, maka ia akan mempelajarinya dalam waktu yang tertentu. Motivasi itu timbul disebabkan ia merasa memerlukan sesuatu dari hal yang dipelajarinya. Menurut Syah (dalam Roida 2012), minat berarti kecenderungan dan kegairahan yang tinggi atau keinginan yang besar terhadap sesuatu.

Berdasarkan hasil pengamatan sepintas penulis di SMAN 4 Palu, diperoleh fakta bahwa di sana minat siswi terkait belajar pendidikan jasmani masih mengundang keperihatinan. Hal ini dapat dilihat pada kurang antusiasnya siswi dalam melakukan tugas gerak yang diberikan guru. Adapun penyebab hal ini berdasarkan wawancara dengan sejumlah siswi adalah: mereka takut bau badan dan berkeringat, takut kakinya mengalami farises, takut item-item kecantikan yang digunakan luntur saat banyak bergerak, dan takut untuk berotot.

Dengan adanya permasalahan di atas, maka guru pendidikan jasmani yang berwenang sepatutnya mendesain strategi pembelajaran yang efektif untuk mengatasi permasalahn yang ada. Adapun sebagai langkah dasarnya adalah mencari tahu secara pasti terlebih dahulu bagaimana sesungguhnya minat siswi terhadap pembelajaran pendidikan Jasmani. Dalam hal ini, cara yang digunakan untuk mengungkapnya tentu saja adalah dengan metode yang ilmiah.

Atas dasar uraian-uraian di atas, penulis tertarik untuk membantu pihak SMAN 4 Palu secara ilmiah mencari tahu bagaimanakah minat siswi di sekolah tersebut terhadap pembelajaran pendidikan jasmani. Adapun langkah yang akan diambil penulis adalah melakukan penelitian dengan mengangkat judul: "Aspek Minat pada Siswi Kelas XI SMAN 4 Palu Terhadap Pembelajaran Pendidikan Jasmani”.

Dengan demikian rumusan masalah dalam penelitian ini adalah: Bagaimana Minat siswi kelas XI SMA Negeri 4 Palu terhadap pelajaran pendidikan jasmani?. Adapun tujuannya adalah untuk mengetahui bagaimana minat siswi kelas XI SMA Negeri 4 Palu terhadap pelajaran pendidikan jasmani. 


\section{B. METODE PENELITIAN}

Penelitian ini dilakukan di kelas XI SMA Negeri 4 Palu Sulawesi Tengah. Ruang lingkup dalam penelitian ini berpusat pada minat, siswi, dan pembelajaran pendidikan jasmani.

Alat atau instrumen yang digunakan dalam penelitian ini adalah angket atau kuesioner. Menurut Sugiyono (2017:142) “Angket adalah cara pengumpulan data yang dilaksanakan dengan jalan memberi sederet pernyataan atau pernyataan tertulis untuk responden guna dijawabnya. Dalam penelitian ini, angketnya berupa kuesioner tertutup, dengan pernyataan yang digunakan dalam angket tersebut adalah jenis pernyataan dengan menggunakan 2 alternatif jawaban yaitu jawaban "Ya" dan jawaban "Tidak", yang diperuntukan untuk responden yang telah di tentukan sebelumnya. Aspek yang diteliti menyangkut : 1). Rasa senang karena kemauan sendiri, 2). Rasa senang karena memiliki bakat, 3). Rasa senang terhadap kesenangan itu sendiri, 4). Rasa senang karna adanya perhatian, 5). Rasa senang karena alat dan fasilitas, 6). Rasa senang karena pengaruh lingkungan, 7). Rasa senang karena pengaruh teman, 8). Rasa senang karena pengaruh keluarga, 9). Rasa senang karena pengaruh adanya motif.

Definis operasional variabel dalam penelitian ini meliputi:

1) Minat: kecenderungan yang timbul apabila individu tertarik pada sesuatu karna sesuai dengan kebutuhan atau merasakan bahwa sesuatu yang akan dipelajari dirasakan bermakna bagi dirinya.

2) Siswi: murid perempuan.
3) Pendidikan Jasmani: bagian integral dari pendidikan total yang mencoba mencapai tujuan untuk mengembangkan kebugaran jasmani, mental, sosial serta emosional bagi masyarakat dengan wahana aktivitas jasmani

Dalam mengubah data tersebut dapat dilakukan dengan cara formula. Rumus presentase umumnya yang digunakan adalah :

$$
\begin{gathered}
F \\
P=\_x 100 \%=\cdots \%
\end{gathered}
$$$$
\text { N }
$$

Keterangan : $\mathrm{P}=$ Prenstase yang dicari

$$
\begin{aligned}
\mathrm{F} & =\text { Frekwensi jawaban } \\
\mathrm{N}= & \text { Jumlah total jawaban } \\
& \text { responden }
\end{aligned}
$$

\section{HASIL DAN PEMBAHASAN}

Bagian ini menyajikan hasil penelitian. Hasil penelitian dapat dilengkapi dengan tabel, grafik (gambar), dan/atau bagan. Bagian pembahasan memaparkan hasil pengolahan data, menginterpretasikan penemuan secara logis, mengaitkan dengan sumber rujukan yang relevan.

\section{Hasil}

Dari jumlah keseluruhan data reponden mengenai minat siswi terhadap Pembelajaran Pendidikan Jasmani Kelas XI di SMA Negeri 4 Palu, maka diperoleh persentase data rasa senang karena diri (intrinsik) seperti pada tabel berikut:

Tabel 1. Persentase data kemauan dari dalam diri (intrinsik) 


\begin{tabular}{|c|l|c|c|}
\hline No. & \multicolumn{1}{|c|}{ Indikator } & \multicolumn{1}{c|}{$\begin{array}{c}P(y a) \\
F\end{array}$} & $\begin{array}{c}\text { P(tidak }) \\
F\end{array}$ \\
\hline 1 & $\begin{array}{l}\text { Rasa senang } \\
\text { karena kemauan } \\
\text { sendiri }\end{array}$ & $87,5 \%$ & $\begin{array}{c}\text { } \\
x 100 \%\end{array}$ \\
\hline 2 & $\begin{array}{l}\text { Rasa senang } \\
\text { karena memiliki } \\
\text { bakat }\end{array}$ & $\begin{array}{l}\text { Rasa senang } \\
\text { karena } \\
\text { kesenangan itu } \\
\text { sendiri }\end{array}$ & $77,38 \%$ \\
\hline 4 & $\begin{array}{l}\text { Rasa senang } \\
\text { karena timbulnya } \\
\text { perhatian }\end{array}$ & $88,23 \%$ & $22,62 \%$ \\
\hline & Total & $76,67 \%$ & $23,33 \%$ \\
\hline
\end{tabular}

Sedangkan untuk persentase data rasa senang karena diri (ekstrinsik), hasilnya adalah seperti pada tabel berikut:

Tabel 2. Persentase data kemauan dari luar diri (ekstrinsik)

\begin{tabular}{|c|l|c|c|}
\hline No. & \multicolumn{1}{|c|}{ Indikator } & \multicolumn{1}{c|}{$\begin{array}{c}P(y a) \\
F\end{array}$} & $\begin{array}{c}P(\text { tidak }) \\
\text { x } 100 \%\end{array}$ \\
\hline 1 & $\begin{array}{l}\text { Rasa senang } \\
\text { terhadap alat dan } \\
\text { fasilitas }\end{array}$ & $92,85 \%$ & $7,14 \%$ \\
\hline 2 & $\begin{array}{l}\text { Rasa senang } \\
\text { karena pengaruh } \\
\text { lingkungan }\end{array}$ & $\begin{array}{l}\text { Rasa senang } \\
\text { karena pengaruh } \\
\text { teman }\end{array}$ & $69,04 \%$ \\
\hline 4 & $\begin{array}{l}\text { Rasa senang } \\
\text { karena pengaruh } \\
\text { keluarga }\end{array}$ & $44,64 \%$ & $30,95 \%$ \\
\hline 5 & $\begin{array}{l}\text { Rasa senang } \\
\text { karena pengaruh } \\
\text { adanya motif }\end{array}$ & $92,85 \%$ & $33,92 \%$ \\
\hline & Total & $74,40 \%$ & $25,59 \%$ \\
\hline
\end{tabular}

Dari paparan tabel di atas, dapat dikemukakan bahwa: a. Terkait aspek intrinsik, besar minatnya mencapai $76,67 \%$. Adapun sisanya (rasa tidak berminat) mencapai $23,33 \%$.

b. Terkait aspek ekstrinsik, besar minatnya mencapai $74,40 \%$. Adapun sisanya (rasa tidak berminat) mencapai $25,59 \%$.

\section{Pembahasan}

Berdasarkan hasil pengolahan data di atas dapat kemukakan dua asumsi. Pertama, pada aspek faktor intrinsik, kadar minat siswi terhadap pembelajaran pendidikan jasmani masih lebih mendominasi ketimbang perasaan tidak berminatnya. Hal ini dapat dibuktikan dengan persentase minatnya yang mencapai $76,67 \%$. Kedua, pada aspek faktor ekstrinsik, kadar minat siswi terhadap pembelajaran pendidikan jasmani masih lebih mendominasi ketimbang perasaan tidak berminanyat. Hal ini dapat dibuktikan dengan persentase minatnya yang mencapai $74,40 \%$.

Dengan hasil ini, dapat dijelaskan bahwa penelitian ini sejalan dengan teori-teori yang ada. Menurut Slameto (2015: 180) bahwa minat adalah suatu rasa lebih suka dan rasa ketertarikan pada suatu hal atau aktivitas tanpa ada yang menyuruh. Minat yang dimaksud akan hadir, bila suatu objek yang dihadapi sesorang bagi kebutuhan hidupnya. Sebagaimana yang kita pahami, pendidikan jasmani adalah sesuatu yang penting bagi setiap siswi.

Skinner (1997 dalam Budiyarti, 2011) berpendapat bahwa minat selalu berkolerasi terhadap objek yang menarik hati seseorang, dan objek yang menarik tersebut ialah yang dirasakan mengasyikan. Jika seseorang memiliki minat akan suatu objek, maka minat itu bisa menuntun 
seseorang untuk berkolerasi semakin dekat dengan objek yang dimaksud, yaitu dengan melaksanakan kegiatan lebih aktif dan positif guna mewujudkan sesuatu yang diminatinya. Dalam hal ini, objek yang menarik bagi siswi mencakup kesenangan, kemauan, bakat, perhatian, keluarga, fasilitas, teman dan motif.

Menurut Budiyarti (2011), secara umum faktor-faktor yang mempengaruhi minat dibagi menjadi dua, yaitu yang bersumber dari dalam diri (faktor internal) maupun yang berasal dari luar (faktor eksternal). Faktor internal terdiri atas niat, rajin, motivasi, dan perhatian. Faktor eksternal terdiri atas keluarga, guru dan fasilitas sekolah, teman sepergaulan, media massa. Penjelasan secara rinci sebagai berikut:

Faktor internal:

1) Niat, niat merupakan titik sentral yang pokok dari segala bentuk perbuatan seseorang.

2) Rajin dan kesungguhan dalam belajar seseorang akan memperoleh sesuatu yang dikehendaki dengan cara maksimal dalam menuntut ilmu tentunya dibutuhkan kesungguhan belajar yang matang dan ketekunan yang intensif pada diri orang tersebut.

3) Motivasi, motivasi merupakan salah satu faktor yang mempengaruhi minat seseorang karena adanya dorongan yang timbul dalam dir seseorang untuk berbuat sesuatu dalam mencapai tujuan.

4) Perhatian, minat timbul bila ada perhatian dengan kata lain minat merupakan sebab akibat dari perhatian, karena perhatian itu merupakan pengarahan tenaga jiwa yang ditujukan kepada suatu obyek yang akan menimbulkan perasaan suka.

5) Sikap terhadap guru dan pelajaran, sikap positif dan perasaan senang terhadap guru dan pelajaran tertentu akan membangkitkan dan mengembangkan minat siswa, sebaliknya sikap memandang mata pelajaran terlalu sulit atau mudah akan memperlemah minat belajar siswa.

Faktor eksternal:

1) Keluarga, adanya perhatian dukungan dan bimbingan dari keluarga khususnya orang tua akan memberikan motivasi yang sangat baik, bagi perkembangan minat anak.

2) Guru dan fasilitas sekolah, faktor guru merupakan faktor yang penting pada proses belajar mengajar, cara guru menyajikan pelajaran di kelas dan penguasaan materi pelajaran yang tidak membuat siswa malas, akan mempengaruhi minat belajar siswa. Demikian halnya dengan sarana dan prasarana yang tidak mendukung seperti buku, ruang kelas, laboratorium yang tidak lengkap, dapat berpengaruh terhadap minat siswa.

3) Teman sepergaulan, sesuai dengan masa perkembangan siswa yang senang membuat kelompok dan banyak bergaul dengan kelompok yang diminati, teman pergaulan yang ada di sekelilingnya berpengaruh terhadap minat belajar anak. Sebaliknya bila rekan bergaulnya tak ada yang bersekolah dan malas bersekolah maka minat belajar siswa bisa berkurang.

4) Media massa, kemajuan teknologi seperti, VCD, Telepon, HP, Televisi dan media cetak 
lainnya seperti buku bacaan, majalah, dan surat kabar, semuanya itu dapat mempengaruhi minat belajar siswa. Bila siswa memakai media tersebut demi membantu proses belajar mengajar maka akan berkembang, tetapi jika masa belajarnya digunakan untuk menonton TV dan digunakan untuk yang lain yang tidak seharusnya tentunya akan berdampak negatif.

Dengan hasil ini, dapat dijelaskan bahwa penelitian ini sejalan dengan teori-teori yang ada. Menurut Valianto \& Hamda (2017:106) bahwa minat merupakan salah satu unsur kepribadian yang memegang peran penting dalam mengambil keputusan masa depan. Apabila seseorang mempunyai minat terhadap suatu objek, maka minat tersebut akan mendorong seseorang untuk berhubungan lebih dekat dengan objek tersebut, yaitu dengan melakukan aktivitas lebih aktif dan positif demi mencapai sesuatu yang diminatinya. Dalam hal ini, objek yang menarik bagi siswi mencakup kesenangan, kemauan, bakat, perhatian, keluarga, fasilitas, teman dan motif.

Menurut Budiyarti (2011), secara garis besar faktor-faktor yang mempengaruhi minat dapat dikelompokkan menjadi dua, yaitu yang bersumber dari dalam diri (faktor internal) maupun yang berasal dari luar (faktor eksternal). Faktor internal meliputi niat, rajin, motivasi, dan perhatian. Faktor eksternal meliputi keluarga, guru dan fasilitas sekolah, teman sepergaulan, media massa. Penjelasan secara rinci sebagai berikut:

\section{Faktor internal:}

1) Niat, niat merupakan titik sentral yang pokok dari segala bentuk perbuatan seseorang.
2) Rajin dan kesungguhan dalam belajar seseorang akan memperoleh sesuatu yang dikehendaki dengan cara maksimal dalam menuntut ilmu tentunya dibutuhkan kesungguhan belajar yang matang dan ketekunan yang intensif pada diri orang tersebut.

3) Motivasi, motivasi merupakan salah satu faktor yang mempengaruhi minat seseorang karena adanya dorongan yang timbul dalam dir seseorang untuk berbuat sesuatu dalam mencapai tujuan.

4) Perhatian, minat timbul bila ada perhatian dengan kata lain minat merupakan sebab akibat dari perhatian, karena perhatian itu merupakan pengarahan tenaga jiwa yang ditujukan kepada suatu obyek yang akan menimbulkan perasaan suka.

5) Sikap terhadap guru dan pelajaran, sikap positif dan perasaan senang terhadap guru dan pelajaran tertentu akan membangkitkan dan mengembangkan minat siswa, sebaliknya sikap memandang mata pelajaran terlalu sulit atau mudah akan memperlemah minat belajar siswa.

Faktor eksternal:

1) Keluarga, adanya perhatian dukungan dan bimbingan dari keluarga khususnya orang tua akan memberikan motivasi yang sangat baik, bagi perkembangan minat anak.

2) Guru dan fasilitas sekolah, faktor guru merupakan faktor yang penting pada proses belajar mengajar, cara guru menyajikan pelajaran di kelas dan penguasaan materi pelajaran yang tidak membuat siswa malas, akan mempengaruhi minat belajar siswa. Demikian pula sarana dan fasilitas yang kurang mendukung seperti buku pelajaran, ruang kelas, 
laboratorium yang tidak lengkap dapat mempengaruhi minat siswa begitu juga sebaliknya.

3) Teman sepergaulan, sesuai dengan masa perkembangan siswa yang senang membuat kelompok dan banyak bergaul dengan kelompok yang diminati, teman pergaulan yang ada di sekelilingnya berpengaruh terhadap minat belajar anak. Sebaliknya bila teman bergaulnya tidak ada yang bersekolah atau malas sekolah maka minat belajar anak akan berkurang atau malas.

4) Media massa, kemajuan teknologi seperti, VCD, Telepon, HP, Televisi dan media cetak lainnya seperti buku bacaan, majalah, dan surat kabar, semuanya itu dapat mempengaruhi minat belajar siswa. Jika siswa menggunakan media tersebut untuk membantu proses belajar mengajar maka akan berkembang, tetapi bila waktu belajarnya dipakai untuk menonton TV atau digunakan untuk yang lain yang tidak semestinya tentunya akan berdampak negatif.

\section{PENUTUP}

Kesimpulan dalam penelitian ini adalah faktor intrinsik dan ekstrinsik masih sama-sama mendominasi minat siswi pada Pembelajaran Pendidikan Jasmani SMA Negeri 4 Palu. Terkait aspek intrinsik, besar minatnya mencapai 76,51\%. Sedangkan terkait aspek ekstrinsik, besar minatnya mencapai $74,40 \%$.

Sebagai saran:

1) Bagi sekolah dan pihak terkait agar melakukan perbaikan sarana dan prasarana olahraga sekolah agar dapat menambah minat belajar siswa.
2) Bagi siswi lebih sadar lagi dalam menjaga dan merawat sarana dan prasarana yang telah disediakan pihak sekolah agar sarana dan prasarana olahraga di SMA Negeri 4 Palu lebih terjaga dan tidak cepat rusak.

3) Bagi guru Pendidikan Jasmani bisa lebih mengembangkan strategi pembelajaran dan mengajar sehingga walaupun sarana dan prasarana minim peserta didik tidak merasa jenuh.

4) Bagi orang tua siswi agar kiranya sangat mendukung anak-anaknya dalam mengikuti pelajaran Pendidikan Jasmani dan memfasilitasi anak-anak mereka sehingga mereka termotivasi untuk belajar.

5) Bagi peneliti lain yang hendak mengadakan penelitian sejenis, hendaknya menjadikan hasil penelitian ini sebagai referensi agar di peroleh hasil yang lebih optimal.

\section{E. REFERENSI}

Budiyarti, Y. (2011). Minat Belajar Siswa terhadap Mata pelajaran Bahasa Indonesia. Skripsi Sarjana pada Fakultas Ilmu Tarbiyah dan Keguruan, UIN Syarif Hidayatullah Jakarta.

Roida, E.,F.,S. (2012). Pengaruh Minat dan Kebiasaan Belajar Siswa terrhadap Prestasi Belajar Matematika. Jurnal Formatif 2 (2).

Slameto. 2015. Belajar dan Faktor-faktor yang Mempengaruhinya. Cetakan Keenam. Jakarta:PT Rineka Cipta.

Sudirjo, E., dan Alif, M.N. (2019). Filsafat Pendidikan Jasmani. Sumedang: UPI Sumedang Press.

Sugiyono. (2017). Metode Penelitian Kuantitatif Kualitatif dan $R \& D$. Bandung: Alfabeta. 
Syahputra, E. (2020). Snowball Throwing Tingkatkan Minat dan Hasil Belajar. Sukabumi: Haura Publishing.

Valianto B \& Hamda, M. Sirait D. Survey Minat Masyarakat untuk Menggunakan Fasilitas Olahrga Di Universitas Negeri Medan. Jurnal Ilmiah Ilmu Keolahragaan Volume 1, Nomor 2 oktober 2017. ISSN 2580-5150 